\title{
Face Threatening Acts in Pre-Service Teachers and Students: A Case Study in EFL Classroom
}

\author{
Jimmy Sapoetra \\ Primary Teacher Education, Faculty of Humanities, Bina Nusantara University \\ jsapoetra@binus.edu
}

\begin{abstract}
Maintaining relationship between teachers and students is one of the key issues in learning process. This issue is important as the relationship affects the process as well as the results of students' learning. It is also significant how the teachers interact with the students in the classroom. In this study the researcher would like to see whether teachers' attitude affects students' perception on such a behavior. This was seen through the language that teachers use in the classroom. Some teachers tend to use face threatening acts (FTA), which cause the students feel uncomfortable, tense, and anxious (Pomerantz 1984, Beebe \& Cummings 1985, Chen, 2006). As a result, the students' learning outcomes might be affected. In some cultures, doing such a thing would be considered impolite. The study was conducted in one of the private senior high schools in Jakarta with a sample of 2 (two) teachers and 50 (fifty) students of Grades 10 \& 11 from two EFL classrooms. A list of questionnaires was used along with an interview with the teachers to clarify the results. The discussion covered several aspects regarding the existence of FTA in EFL classrooms: the kinds of threatening acts used, the patterns of the threatening acts, the factors of using threatening acts, and the students' responses of threatening acts. It was found that there were 11 indirect threats being used by the teachers. Another FTA being used was the indirect accusation. The interview also shows that the pre-service teachers were not aware that such attitude affects the students' perception and learning behavior in the classroom. Thus, the study was expected to give insights for the pre-service teachers in EFL classroom on how they should behave and utter in the learning process.
\end{abstract}

Keywords: EFL Classroom; Face Threatening Acts; Pre-Service Teachers

\section{Abstrak}

Menjaga relasi antara guru dan siswa adalah salah satu isu utama dalam Pendidikan. Isu ini penting karena relasi yang baik mempengaruhi baik proses maupun hasil pembelajaran siswa. Bagaimana guru berinteraksi dengan siswa di kelas juga menjadi penting. Dalam studi ini ingin dilihat bagaimana sikap guru mempengaruhi persepsi siswa terhadap perilaku tersebut. Hal ini terlihat melalui bahasa yang digunakan guru di kelas. Beberapa guru cenderung menggunakan FTA yang mengakibatkan siswa merasa tidak nyaman, tegang, dan kuatir (Pomerantz 1984, Beebe \& Cummings 1985, Chen, 2006). Akibatnya, hasil belajar siswa terganggu. Dalam budaya tertentu, melakukan hal tersebut dianggap tidak sopan. Studi ini dilakukan di salah satu SMA swasta di Jakarta dengan sampel dua guru dan 50 siswa kelas $10 \& 11$ dari dua kelas EFL. Studi ini menggunakan pendekatan kualitatif dan kuantitatif dengan bantuan statistik deskriptif untuk menganalisa hasilnya. Sejumlah angket digunakan dengan wawancara bersama dua guru untuk mengklarifikasi hasilnya. Diskusi ini meliputi beberapa aspek mengenai keberadaan FTA dalam kelas EFL: bentuk FTA yang digunakan, pola FTA yang terjadi, faktor-faktor penggunaan FTA, dan respon siswa terhadap FTA. Studi ini diharapkan untuk memberikan inspirasi kepada guruguru yang baru mengajar di kelas EFL.

Kata Kunci: Face Threatening Acts; Guru Magang; Kelas EFL 


\section{INTRODUCTION}

One of the major issues in EFL classroom is how the teachers talk to the students and how they use the utterance. Thus, how the teachers maintain the class in such a way that the students behave appropriately and accordingly based on the school's policy. Face Threatening Acts (FTA) us one of the most popular issues in the teacher's talk in the classroom. The main purpose of the use of FTA is to make sure that the students are in control in their behavior. The major concerns discussed in classroom-oriented research may be related to teachers' teaching effectiveness and students' learning outcomes. It was found that teacher talk plays a major role in teaching and learning in classroom settings and has a significant part of classroom instruction (Dörnyei \& Murphey, 2003; Bishop \& Glynn, 1999; Brown, 2007). The degree of face threats depends on the variables of social power, social distance, and imposition. (Culpeper, 2005).

Nevertheless, in classroom settings, the teacher (speaker) is clearly more powerful in some sense than the students (hearer). Firstly, the climate of a classroom is not always supportive and sometimes even conflictive. Since the mid-1960s, researchers have suspected that anxiety inhibits foreign language learning. Secondly, although most experienced language teachers recognize that anxiety is not a positive ingredient for successful learning in the teaching process, some still believe students' unfavorable behavior in class needs to be prohibited by using certain verbal threats. Thirdly, these circumstances may cause conflict between the teacher and students; various teachers argue for conflicting beliefs regarding whether or not teachers ought to use threatening acts in class.

The use of FTA is crucial on the students' learning outcome. Students indicated that the use of threats in class may make them feel depressed, increase class tension, and affect classroom atmosphere. The politeness theory proposed by Brown and Levinson (1978) is one of the most comprehensive and widely tested theories in the field of pragmatic politeness. It covered many areas and proved to be highly applicable in most cultures. Brown and Levinson introduced the concept of "face" into politeness theory. The term face expresses that people need to be recognized and respected by other people. According to Brown and Levinson the term "face" consists of two related aspects, positive face and negative face. Positive face includes the desire that the selfimage should be appreciated and approved by somebody else. Negative face is the basic claim to territories, personal preserves right to without destruction; it means the freedom of action and freedom from any burden. Brown and Levinson (1978) conceptualize face as something that we want or desire from others. They define face as "the want to be unimpeded and the want to be approved of in certain respects (p. 63)." They argue that when people interact with one another they recognize each other's desire to have their faces supported and generally provide such confirmation. Approval is reflected in the way that other people respond to usshowing respect and honor. Analysis of the Face Threatening Act is interesting because people usually cooperate in maintaining face in interaction.

Face Threatening Act is something which is not really understood by both teachers and students. In the previous studies, most researchers were focusing on the classrrom management rather than how the teachers In order to maintain the classroom atmosphere as well as the students' discipline, pre-service teachers usually use some expressions which create tense and uneasy atmosphere in the classroom. Serious pedagogical implications might occur if this phenomenon is not changed. The study is trying to investigate the effect of such behavior as well as the possible solution to it.

\section{Background of the Study}

This study was carried out to find out how face threatening acts were used by pre-service teachers in EFL classroom and how it might affect the students' learning outcome out of such behavior. These circumstances may cause conflict between the teacher and students. The purpose of the study is to investigate whether or not teachers ought to use threatening acts in the class. In addition, students' perceptions of the use of threatening acts by teachers are determined. The study is trying to investigate the following:

1. How the teachers use face threatening acts in the classroom.

2. Students' perception of the use of face threatening acts in the classroom.

The study wants to answer the following questions: 
1. What are the face threatening acts used by pre-service teachers in the EFL classroom?

2. Are there patterns of the pre -service teacher's use of threatening acts?

3. What are the factors affecting pre-service teachers' use of threatening acts?

4. How do the students perceive the teachers' use of threatening acts?

\section{LITERATURE REVIEW}

'face' is a linguistic term that is used in semantics, pragmatics, sociolinguistics, as well as sociology, psychology, and political science (Lonel, 2011: 76). The term is now used in different cultures in a metaphorical sense to mean the reputation or the standing in the society (ibid.). Goffman (1955:338) defines the term as "the positive image you seek to establish in social interactions".

Brown and Levinson (1987:65) believe that in performing a particular speech act in a particular context, the face-wants of the participants are threatened and politeness takes place to modify these face threatening acts. Furthermore, The counteractions that the participants make when they fail to perform a selfimage competently are called 'face-work' (ibid.). Thomas (1995: 158) indicates that politeness makes an equality in any social interaction. Politeness is a pragmatic theory that means " saying the socially correct thing...(and) is developed by societies in order to reduce friction in personal interaction" (Lakoff, 1975: 53,64). Brown and Levinson's (1987) theory of politeness is still the basis for the latter theoretical and empirical works on this theory (i.e. Kasper, 1990; Harris, 2003 and Ellis, 2008).

Brown and Levinson (1987:61) define face as a linguistic term with an emotional effect that can be lost, saved, or improved. When speakers interact, they try to maintain face in interaction; they do so by relying on 'mutual vulnerability of face' (ibid.). They also state that the notion of face has a dual nature: positive and negative face. The positive face is the positive desire of members for approval; the negative face, on the other hand, is the participants' desire for freedom of action and from imposition (ibid.:62).

According to Chen (2017), there are 4 (four) main types of FTA (indirect threats, indirect accusation, direct threats with modified blame, and direct threats with explicit blame). Indirect threats were used most frequently, followed by direct threats with explicit blame, direct threats with modified blame, and indirect accusation. Students' unfavorable behavior and the supervising system during class time were the main factors leading the teacher to use threatening acts in class. Maintaining silence was the most frequent response of the students after receiving the teacher's indirect threats, whereas for other threat types, improvement of behavior was the most frequent response. Students indicated that the use of threats in class may make them feel depressed, increase class tension, and affect classroom atmosphere.

Thomas (1995: 158) indicates that politeness makes an equality in any social interaction. Politeness is a pragmatic theory that means " saying the socially correct thing...(and) is developed by societies in order to reduce friction in personal interaction" (Lakoff, 1975: 53,64). Brown and Levinson's (1987) theory of politeness is still the basis for the latter theoretical and empirical works on this theory (i.e. Kasper, 1990; Harris, 2003 and Ellis, 2008).

The term 'polite' is fundamentally derived from the Latin word 'poiltus' meaning 'to smooth' (Sifianou, 1992:81). Subsequently, the term is now used to mean: 'refined', 'cultivated' and so on, when describing people; and 'courteous', 'urban', etc., when describing manners (ibid.).

Leech (1980:19) defines the politeness as "strategic conflict avoidance". It refers to those types of behaviour that are used to make and support the cooperation of participants in a comity environment (ibid.). Hill et al (1986: 349) produce a similar definition: "politeness is one of the imperatives on human connection, whose reason for existing is to think about others' sentiments, build up levels of shared solace, and advances compatibility". Many different fields of study are involved in the study of politeness such as pragmatics, stylistics, and conversational analysis (El-Samir, 2014: 4).

Culpeper's (1996) showed that model of impoliteness and theory of politeness (2005) proved useful in classifying the impoliteness strategies in different discourse types in general. It studied impoliteness strategies, sub-strategies, types of attack (related to face or sociality rights) and the response to such attacks whether offensive or defensive.

Another study conducted by Szczepaniak-Kozak (2016). In his study, impoliteness is multifaceted and noticeable as defined by Culpeper (1996) as follows: attacking the addressee's need to be unimpeded, sarcasm or mock politeness - use of insincere politeness strategies or withholding politeness. Irony or scorn remained a frequent impoliteness strategy. Simultaneously, explicitly putting the hearer in the position of blame by 
means of you became the most frequent negative impoliteness strategy. It was also assumed that the development of pragmatic competence in EFL learners takes a different path from that of characteristics of native English acquisition.

Face Threatening Act (FTA) refers to the communication act that causes a threat to the individual's expectations regarding self-image (Yule, 1996: 61). Goffman (1955:215) uses different terms to describe such situations; for instance, "in the wrong face", "to be out of face", "shamefaced", and "threats to face".

Brown and Levinson (1987: 65) mention that these acts are used as a keynote for the politeness theory. They define these acts as " acts that by their very nature run contrary to the face wants of the addressee and/or the speaker " (ibid.). Depending on the hearer's perception, the act itself forms a threat that violates both, hearer's and speaker's face.

Such acts can also be threats not only to the hearer's face, but also to the speaker's face if the speaker performs acts that are opposites to his or her wants and desires.

Brown and Levinson (1987: 65) define face threatening acts according to two main elements: "Whose face is being threatened (the speaker's or the addressee's), and which type of face is being threatened (positiveor negative- face)". "A hearer's positive face threatening acts are complaints, criticisms, accusations, mention of taboo topics, interruptions". Acts that threaten an addressee's negative face include offers, promises. "Examples of face threatening acts to the speaker's positive face include confessions, apologies, acceptance of a compliment, and self humiliations". Some of the face threatening acts that are threatening to the speaker's negative face include "expressing gratitude, accepting a thank-you, an apology or an offer, and making promises"(ibid.).

\section{METHODS}

The study observed the kinds, the patterns, and the factors of threatening acts of pre-service teachers as well as students' perception in EFL classroom. The research methods used were classroom observation, an interview, and an open-ended questionnaire. The students' perception was also investigated.

\section{Data Resources}

The data were taken from a private senior high school located in West Jakarta, with a total of approximately 150 students. There were 6 EFL classrooms respectively.

\section{Data Collection Technique}

The students were recorded during the classroom activities and later were asked to fill out a questionnaire describing their perception on the teachers' behavior regarding the face threatening acts in the classroom.

\section{Data Analysis} activities.

The data then were analyzed to find out whether there were face threatening acts during the classroom

\section{FINDINGS AND DISCUSSION}

After observing the classes to see whether Face Threatening Acts (FTA) occurred in the classrooms, an interview was conducted to clarify the pre-service teachers regarding the FTA. The findings covered both data from the male and female teachers.

To answer the first question, a total of 12 threatening acts were observed. There were four types of threat proposed by Chen (2017), 1) indirect threats (avoiding explicit mention of the students), 2) indirect accusations (involving questions to students about their unfavorable behavior), 3) direct threats with modified blame (with softer expression), and 4) direct threats with explicit blame. Interestingly, 11 FTAs found were classified only as indirect threats where teachers avoided to mention the students and 1 FTA was classified as an indirect accusation.

In general, the situations of the classroom showed a very dynamic activity. There were a variety of classrooms activities contained presentation, practice and production stages. Similarly, the teacher's behavior 
was a little bit disruptive as they were novice teachers, in this case fresh graduates and being pre-service teachers.

The second question was whether the patterns of the teacher's use of threatening acts exist. The data from the video showed that in most circumstances, the FTAs occurred during the practice stage. The data from the video showed that in most occurrences, the FTAs happened during the practice stage. It could be assumed that students were enthusiastically discussed the materials or deliberately took their freedom in expressing themselves during the lesson.

Dörnyei \& Murphey (2003) assert that that teacher talk plays a major role in teaching and learning in classroom settings and comprises a significant part of classroom instruction. Looking at how a classroom situation played an important role in the learning proccess, a noisy and unregulated students' activities might jeopardize a conducive classroom atmosphere. Therefore, the fact that the teachers used her FTAs could be justified to secure the conducive classroom situation.

The third question was a crucial one as this was the motivation why the pre-service teachers used the FTAs during the classroom activities. One of the main reasons was that they thought by doing it the students would behave appropriately and nicely. This turned out to be wrong as the students didn't feel comfortable during the lesson. During all of their eight-time teaching practice at school, the student-teachers realized that they utilized very little FTAs apart from the fact that the classroom situations sometimes got out of controlled. Justification of being out of controlled: Teachers' depiction regarding how talkative and noisy the students were and some of them deliberately wander around the classroom doing idle things. The second justification came from the scene where one of the teachers came to the class due to the classroom loud noise that might disturb the next class.

The student-teachers admit to minimize the use of FTAs in class for few reasons. The belief that their first impressions upon the students during their preliminary observation prior to the teaching practice were all positive. They perceived the students as cooperative, obedient, and active. The mentors' direction which reminded them not to get too emotional or angry for any reason. They believed that building a good relationship was totally essential in conducting a teaching learning process. Both of them did not want to sacrifice the trust between them and the students. Therefore, it could be interpreted that they tended to be lenient in tolerating undisciplined behavior in order not to intimidate the students' positive and negative face. The fact that indirect threats by avoiding explicit mention of the students was employed by the teachers might be interpreted as an attempt to protect the students' personal territory.

Last but not least, the students' perceptions regarding the FTAs were varied. Some of them were terrified while others felt uneasy. The students were uncomfortable during the lesson as the teachers kept on using the FTAs in their interaction. In general, the students' responses described the students' perceptions regarding the teachers and their teaching. The questionnaire results would be divided into two perspectives: Suggestions on the student-teacher important qualities in the behavior of a good teacher and on the qualities they need to improve. Out of 24 qualities being evaluated by the students, 13 qualities were considered already good and were suggested to be maintained. 11 qualities needed to be improved or paid attention to. The priorities of attention should be given to two qualities: giving motivation and giving individual attention.

The fact that teachers restrained themselves for being more confirmed towards classroom management or discipline was also felt by some students in the class. If only more classroom management techniques trained and practiced by the pre-service teachers, they could be more confident in utilizing their classroom interaction including their FTAs with strategies for "going on records" like what had been shared by Chen (2017).

Going on record, along with positive or negative politeness, leads to the strategies of positive or negative politeness. Positive politeness can be realized as suggesting commonality, understanding, and joint action, whereas negative politeness is expressed by showing respect and maintaining social distance (Chen, 2017, p.154)

\section{CONCLUSION AND SUGGESTION}

The study investigated the pre-service teachers' use of FTAs in EFL classrooms. In particular, it explores the kinds, patterns of the FTAs occurred during the classroom activities, later also the students' perception of the teachers' use of FTAs. The results from the classroom observations, the teachers' interviews, and the students' questionnaires showed several conclusions. 
First, there were 12 occurrences of FTAs that were observed during three-times teaching done by both pre-service teachers. 11 FTAs were categorized as indirect threats where teachers avoided to mention the students and 1 FTA was categorized as an indirect accusation. (involving questions to students about their behavior). Second, the patterns showed that in most circumstances, the FTAs occurred during the practice stage. Third, there were at least three reasons why they both decided to employ such FTAs. The first reason was that their first impressions upon the students during their preliminary observation prior to the teaching practice were all positive. The second reason was their mentors' suggestion which reminded them not to get too emotional or angry. The third reason came from their belief that for most of the cases where students tended to get attention were resulted from their needs to be acknowledged.

Lastly, according to the students' perceptions, both pre-service teachers already performed well. However, it was believed that there were always rooms for improvement. Between $25 \%-40 \%$ of the students suggested that the pre-service teachers could have improved their qualities in giving motivation and individual attention. Furthermore, after talking to the teachers and looking at how students perceived their teachers, both parties believed that there were areas to improve or maintain. The fact that teachers restrict themselves towards classroom management or discipline was also noticed by some students.

As a pedagogical implication, if only more classroom management techniques practiced by the preservice teachers along with the experience of real classroom exposures had been given earlier, the pre-service teachers could have been more confident in managing their classroom activities where FTAs were used for better purposes. In other words, teachers must be aware of the use of FTA in the class and how they affect the learning process.

\section{REFERENCES}

Bishop, R. and Glynn, T. (1999) Culture Counts: Changing Power Relations in Education. Dunmore Press Ltd., Auckland.

Brown, H. D. (2007). Principles of Language Learning and Teaching Fifth Edition. New York, Longman.

Brown, P., Levinson, S. C. (1978). Universals in language usage: Politeness phenomena. In Goody, E. N. (Ed.), Questions and politeness: Strategies in social interaction (pp. 56-289). Cambridge, UK: Cambridge University Presss

Brown, P., \& Levinson, S. C. (1987). Politeness: Some universals in language usage. Cambridge University Press.

Chaudron, C. (1988). Second Language Classroom: Research on Teaching and Learning.

New York: Cambridge University Press. https://doi.org/10.1017/CBO9781139524469

Chen, I. J. (2017). Face-Threatening Acts: Conflict between a Teacher and Students in EFL Classroom. Open Journal of Modern Linguistics, 7,151-166. https://doi.org/10.4236/ojml.2017.72012

Culpeper, J. (2005). "Impoliteness and the Weakest Link." Journal of Politeness Research, 1 (I), 35-72.

Dörnyei, Z. \& Murphey, T. (2003). Group dynamics in the language classroom. Cambridge: Cambridge University.

Ellis, R. (2008) The study of second language acquisition . Oxford: Oxford University Press.

Ewald, J. D. (2007). Foreign Language Learning Anxiety in Upper-Level Classes: Involving Students as Researchers. Foreign Language Annals, 40, 122-142. https://doi.org/10.1111/j.1944-9720.2007.tb02857.x

Goffman, E. (1955). On face-work: an analysis of ritual elements in social interaction. Psychiatry: Journal for the Study of Interpersonal Processes.

Harris, A., \& Muijs, D. (2003). Teacher leadership and school improvement. Education Review, 16, 39-42.

Hiraga, M. K., \& Turner, J. M. (1996). Differing Perceptions of Face in British and Japanese Academic Settings. Language Sciences, 18, 605-627.

Jaszczolt, K. M. (2002). Semantics and Pragmatics: Meaning in Language and Discourse. London: Longman.

Kasper, G. (1990). Linguistic Politeness Current Research Issues. Journal of Pragmatics, 14, 193-218.

Lakoff, Robin. 1975. Language and woman's place. New York: Harper \& Row.

Lonel, S. (2011). Explicit Teaching of the Pragmatic Concept of Face. The Bucharest Academy of Economic Studies, Youth on the move. Teaching languages for international study and career-building. 
Sadeghoghli, H., Niroomand, M. (2016) Theories on Politeness by Focusing on Brown and Levinson's Politeness Theory. International Journal of Educational Investigations. 3 (2). 26-39. Retrieved from http://www.ijeionline.com/attachments/article/51/IJEI.Vol.3.No.2.03.pdf

Shi, X. (2012). Negotiating power and access to second language learners: A Study on Short-term Chinese MBA students in America. The Modern Language Journal. 95 (4). 575-588. Retrieved from http://www.jstor.org/stable/41413381

Szczepaniak-Kozak, A. (2016). Impoliteness in interlanguage requests of EFL learners in Poland. Linguistica Copernicana. 13. 319-334. http://dx.doi.org/10.12775/LinCop.2016.016.

Thomas, J. (1995). Meaning in Interaction: An Introduction to Pragmatics. London: Longman.

Warner, C. (2009). Hey, you! The Germans! Using Literary Pragmatics to Teach Language as Culture. Teaching German. 42 (2). 162- 168. Retrieved from : http://www.jstor.org/stable/40608635

Zhang, D. (2001). The speech act of complaining: A Cross-cultural Comparative Study of Chinese and American English speakers. Retrospective Theses and Dissertations. 16213. Retrieved from http://lib.dr.iastate.edu/rtd/16213 